\title{
Elevated Free Cholesterol Content in Hindleg Muscle of the Dystrophic Mouse during a Postnatal Period from 2.1 to 30 Weeks
}

\author{
Tsuyoshi TOTSUKA and Kimi WATANABE \\ Department of Physiology, Institute for Developmental Research, Aichi Prefectural \\ Colony, 713-8 Kamiya-cho, Kasugai-shi, Aichi 480-03, Japan
}

(Received for publication: July 14, 1981)

\begin{abstract}
Age-related changes in phospholipid and free cholesterol contents of hindleg muscles from normal and dystrophic (C57BL/6J $d y / d y$ ) mice were investigated. Free cholesterol contents in liver, whole blood and brain of dystrophic mice at 3 weeks of age were also compared with the control. Free cholesterol content tended to increase in the liver of the dystrophic mouse. Free cholesterol content of dystrophic muscle was significantly higher than that of normal muscle at each age (2.1 to 30 weeks old), while phospholipid contents in dystrophic muscles were nearly equal to those of the normal in age from 4 to 20 weeks.
\end{abstract}

Since a hereditary disease in mice (dystrophia muscularis) similar in many ways to the disease in man was reported by Michelson et al. in 1955 [9], voluminous data concerning the pathology of murine muscular dystrophy have been accumulated [5-7]. Based on these findings, various therapeutic trials have been performed to alter the course of the dystrophic process [2], although its fundamental etiology is still unknown. Recently, based on the results from comparative studies between the fore- and hindlegs of the dystrophic mouse $[12,16]$, we have proposed a working hypothesis [13] that the development of murine muscular dystrophy symptoms may be due to an age-related increase in the imbalance between growth-arrested muscles and bones growing almost normally in length. We further reported [14] that the dystrophic symptom (dragging of hindlegs) is masked in genotypically dystrophicdwarf mice (BL-DW $d y / d y \mathrm{~d} w / d w$ ), as evidence supporting this hypothesis.

A question of much importance in our thinking about murine muscular dystrophy is now what mechanism is present in the impaired growth of muscle, possibly resulting from some maturational defect of muscle fibers. Maturational defects, which were observed by us $[11,15]$ and others $[4$, $10]$, may possibly have resulted from altered membrane properties induced by elevated cholesterol content in dystrophic muscle. Thus, in order to examine whether the elevated cholesterol in dystrophic muscle may be a principal factor underlying the course of murine muscular dystrophy, we investigated the age-related changes in free cholesterol and phospholipid contents of hindleg muscle in the dystrophic mouse.

Homozygous dystrophic $(d y / d y)$ mice which showed a dystrophic symptom (dragging of hindlegs) and their phenotypically normal $(d y /+\&+/+)$ littermates were obtained by mating heterozygous dystrophic mice(C57BL/6J $d y /+)$. Homozygous normal mice were obtained by mating $\mathrm{C} 57 \mathrm{BL} / 6 \mathrm{~J}$ mice $(+/ t)$. Mice were killed at various ages by cervical dislocation. From the 
hindlegs, whole muscle was removed after sharp dissection of all visible fat, weighed carefully, minced with scissors as fine as possible, and homogenized at $0^{\circ} \mathrm{C}$ in a Polytron PT-10 with a small volume of 0.1 $\mathrm{M} \mathrm{KCl}-20 \mathrm{mM}$ Trismalate buffer ( $\mathrm{pH} \mathrm{7.0)}$. After the homogenate was immersed in 30 volumes of ethanol-acetone $(1: 1 \mathrm{v} / \mathrm{v})$ mixture, the extraction and determination of free cholesterol were performed according to the method described by Brown et al. [1]. Phospholipid content was determined as follows : The homogenized muscle was washed thrice with $7 \%$ cold trichloroacetic acid to remove acid-soluble materials and then with $80 \%$ ethanol. From the debris, phospholipids were extracted with a boiling ethanol-chloroform $(3: 1 \mathrm{v} / \mathrm{v})$ mixture (thrice). After the extract was dried in an evaporative condenser, phospholipids were reduced to ashes in a $\mathrm{HClO}_{4}$ $\mathrm{H}_{2} \mathrm{SO}_{4}(4: 1 \mathrm{v} / \mathrm{v})$ mixture at $140^{\circ} \mathrm{C}$. Then, phosphorus was determined according to the method of Martin and Doty [8]. All reagents used were of analytical grade.

Phospholipid is a major component of biomembranes including plasma membrane, where cholesterol is believed to be present almost exclusively. At present, it is accepted that properties of biomembranes are heavily dependent on their cholesterol/ phospholipid ratio $[3,17]$. Thus, at first, phospholipid-phosphorus (PL-P) content in normal and dystrophic muscles was compared, where a total of 60 homozygous normal mice and the same number of dystrophic mice were used. As shown in Fig. 1, PL-P contents on a wet weight basis remained almost constant irrespective of age both in normal and dystrophic muscles, and they did not differ between normal and dystrophic muscles at each age during the postnatal period from 4 to 20 weeks. This means that PL-P content of muscle is virtually proportional to its wet weight, suggesting that internal membrane systems developed very well throughout normal and dystrophic muscles. Thus, the following results are expressed on a wet

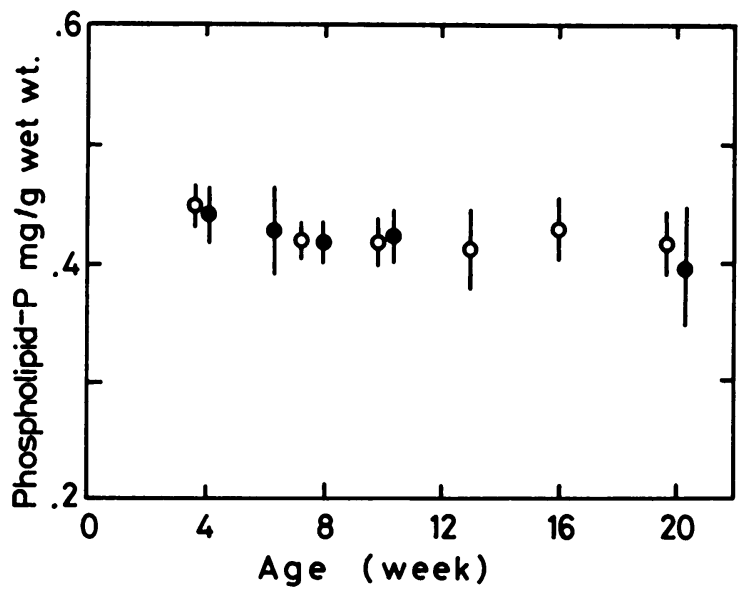

Fig. 1 Phospholipid-phosphorus contents of hindleg muscles from normal $(O)$ and dystrophic (O) mice. Results are shown as means \pm s. $d$. The number of mice used for each mean is 8 to 14 .

weight basis.

Free cholesterol contents of normal and dystrophic muscles were measured, where a total of 90 homozygous normal and 70 homozygous dystrophic mice ranging in age from 2.1 to 30 weeks were used. It was impracticable to analyze the muscle from dystrophic mice younger than two weeks because they could not be distinguished from phenotypically normal littermates before this age. In Fig. 2, the age-related changes are presented. Free cholesterol content of normal muscle decreased markedly with age, e. g., from about $1.4 \mathrm{mg} / \mathrm{g}$ wet weight at 2.1 weeks old to about 0.9 $\mathrm{mg} / \mathrm{g}$ wet weight at 11 weeks old. Free cholesterol content of dystrophic muscle also decreased from about 1.8 to $1.3 \mathrm{mg} / \mathrm{g}$ wet weight during the similar period. However, free cholesterol content of dystrophic muscle was always significantly higher than that of normal muscle at each age examined (e. g., $\mathrm{P}<0.001$ at 3 weeks old; $t$ test). In the present results, it is noteworthy that the ratio of dystrophic to normal value little changed during the postnatal period from 2.1 to 30 weeks (e. g., 1.3 at 2.1 weeks old and 1.4 at 30 weeks 


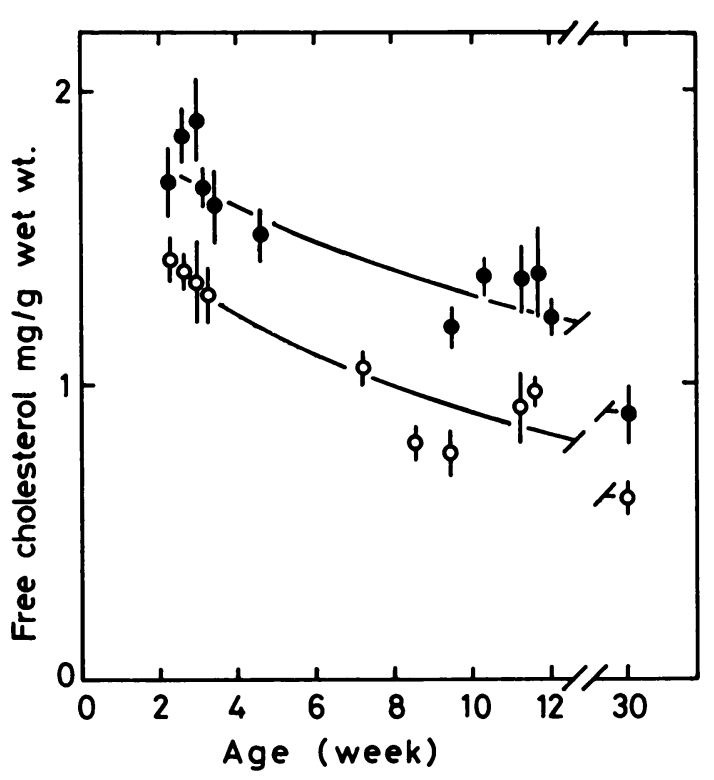

Fig. 2 Age-related changes in free cholesterol contents of hindleg muscles from normal (O) and dystrophic (O) mice. Results are shown as means $\pm \mathrm{s}$. d. The number of mice used for each mean is 4 to 10 .

old). This suggests that free cholesterol content of dystrophic muscle may have already been much higher than that of normal muscle at preclinical stages (before two weeks old).

Free cholesterol contents of liver, whole blood and brain from dystrophic mice and their phenotypically normal littermates were determined similarly with that of muscle. The results are presented in Table 1. Increased free cholesterol content of dystrophic mouse liver was seen, while its levels in whole blood and brain were comparable in dystrophic mice and their littermates. The mean value of blood from dystrophic mice was a little higher than from their littermates but was remarkably lower than in the other tissues examined.

Previously, we reported that apparent cell volume in normal muscle increased drastically with age [11]. This may in part account for the present findings that free cholesterol content decreased with age, whereas phospholipid-phosphorus content remained virtually constant irrespective of age. This is because the surface area of muscle fibers relative to their volume may be expected to decrease with age. Also in dystrophic muscle, a similar explanation may be partly possible. In contrast to our previous biochemical findings [11] that apparent cell volume appeared to remain virtually unchanged irrespective of age, we further found from histological studies [15] that the diameter of some fibers increased with age, though the diameter of the major fibers remained almost constant at the level of about 20 days of age.

Free cholesterol content of dystrophic muscle was always significantly higher than that of normal muscle during the postnatal period from 2.1 to 30 weeks. If the elevated free cholesterol content in dystrophic muscle is solely associated with

Table 1. Free cholesterol contents of hindleg muscle, liver, whole blood and brain from dystrophic mice and their phenotypically normal littermates ( 3 weeks old).

\begin{tabular}{lcrc}
\hline & \multicolumn{2}{c}{ Free cholesterol $\mathrm{mg} / \mathrm{g}$ wet weight } & \\
\cline { 2 - 3 } & \multicolumn{1}{c}{ Dystrophic } & Normal & P \\
\hline Muscle & $1.67 \pm 0.06(11)$ & $1.29 \pm 0.06(23)$ & $<0.001$ \\
Liver & $2.90 \pm 0.19(11)$ & $2.67 \pm 0.22(23)$ & $<0.05$ \\
Blood & $0.88 \pm 0.02(3)$ & $0.83 \pm 0.05(5)$ & N. S. \\
Brain & $13.60 \pm 0.54(4)$ & $13.70 \pm 0.78(12)$ & N. S. \\
\hline
\end{tabular}

Results are shown as means $\pm \mathrm{s}$. d. The number of mice used for each mean is given in parentheses. $P$; t test. 
muscle fibers that undergo progressive degeneration, less extensive changes in free cholesterol content would be expected in the young dystrophic mouse than in the adult dystrophic mouse. However, the ratio of free cholesterol content of dystrophic muscle to that of normal muscle remained virtually constant irrespective of age. This suggests that an intrinsic defect in the pattern of distribution (or the metabolism) of cholesterol may be involved in the course of murine muscular dystrophy. A possible relationship between the elevated free cholesterol content and the maturational defects of muscle fibers in the dystrophic mouse has already been discussed elsewhere [15].

This study was supported in part by research grants from the Ministry of Health and Welfare of Japan and from the Ministry of Education, Science and Culture of Japan.

\section{References}

[1] Brown, H. H., Zlatkis, B., and Boyle, A. J. (1954). Anal. Chem., 26, 397-399.

[2] Cosmos, E., and Butler, J. (1980). Muscle \& Nerve,
3, $427-435$.

[3] Deuticke, B., and Ruska, C. (1976). Biochim. Biophys. Acta, 433, 638-653.

[4] Farnbach, G. C., Brown, M. J., and Barchi, R. L. (1978). Exp. Neurol., 62, 539-554.

[5] Harman, P. T., Tassoni, J. P., Curtis, R. L., and Hollinshead, M. B. (1963). In Muscular Dystrophy in Man and Animals, pp. 407-456, Bourne, G. H., and Golarz, M.M. (edit.), S. Kargar, Basel.

[6] Hayashi, Y., Suzuki, H. O., and Totsuka, T. (1975). J. Biochem. (Tokyo), 77, 761-768.

[7] Hoh, J. F. Y., and Salafsky, B. (1972). Exp. Neurol., 37, 639-642.

[8] Martin, J. B., and Doty, D. M. (1949). Anal. Chem., 21, 965-967.

[9] Michelson, A. M., Russell, E. S., and Harman, P. T. (1955). Proc. Nat. Acad. Sci. (USA), 41, 1079-1084

[10] Summers, P. J., and Parsons, R. (1978). J. Neurol. Sci., 39, 295-301.

[11] Totsuka, T., and Watanabe, K. (1976). Medicine and Biology, 93, 203-206 (in Japanese).

[12] Totsuka, T., and Watanabe, K. (1979). Medicine and Biology, 98, 149-152 (in Japanese).

[13] Totsuka, T., and Watanabe, K. (1979). Medicine and Biology, 99, 1-5 (in Japanese).

[14] Totsuka, T., Watanabe, K., and Kiyono, S. (1981). Proc. Japan Acad., 57B, 109-113.

[15] Totsuka, T., Watanabe, K., and Kiyono, S. (1981). Cong. Anom., 21, 253-259.

[16] Watanabe, K., and Totsuka, T. (1979). Medicine and Biology, 98, 257-260 (in Japanese).

[17] Wiley, J. S., and Cooper, R. A. (1975). Biochim. Biophys. Acta, 413, 425-431.

\title{
2. 1一30 週齢の筋ジストロフィ一症マウスの後肢筋における
}

\author{
異常に高い遊離コレステロール含量 \\ 戸塚＼cjkstart武・渡辺貴美 \\ 愛知県心身障害者コロニー発達障害研究所生理学部
}

筋ジストロフィー症マウス $(\mathrm{C} 57 \mathrm{BL} / 6 \mathrm{~J} d y / d y)$ と 正常マウスの後肢筋に批ける, リン脂質と遊離コレステ ロール含量の, 加齡に伴ら変動を調べた。また， 3 週齢 の罹患および正常マウスの肝, 全血, 脳に护ける遊離コ レステロール含量を調べたところ, 䍜患マウスの肝で少
し高い傾向があることが分かった。罹患筋の遊離コレス テロール含量は, 生後 2.1 から30週龄にわたって, 正常 筋の值より有意に高かった。ところが，罹患筋のリン脂 質の含量（リンを定量）は，4-20週齢にわたって，正常 筋の值とほぼ同様であった。 